\title{
PEMBINAAN KETERAMPILAN KOMUNIKASI BAHASA INGGRIS MELALUI METODE PERMAINAN SUSUN KATA PADA KOMUNITAS BELAJAR CAPUNG KAMPUNG TUA NONGSA BATAM
}

\author{
Alpino Susanto \\ Universitas Karimun (UK), Tanjung Balai Karimun, Indonesia \\ e-mail: susanto.alpino40@gmail.com \\ Zia Hisni Mubarak \\ Universitas Putera Batam (UPB), Batam, Indonesia \\ e-mail: zia.hisni@puterabatam.ac.id
}

\begin{abstract}
English today has become a very important expertise. English is used in a variety of formal and informal settings. This coaching activity targets students in the Capung community in Kampung Tua Nongsa, Batam. From observations made by the team to the community of Kampung Tua Nongsa, especially in the Capung community which consists of students from various educational and occupational backgrounds, communication using English is appropriate which is difficult and cannot be directly applied in their lives. The tourism potential and wisdom of the people who inhabit Kampung Tua Nongsa are very large and the expertise of English for young people is certainly expected to sustain the tourism sector in the region. This activity aims to optimize the basic English skills that students have in communicating both oral and written. Efforts to increase the confidence of English learners is important for those who are just about to start using English in daily communication. The game method that will be applied to this coaching is a fun learning approach. The game that is applied to the learning process is one useful strategy for increasing the amount of vocabulary in communicative language concepts. It is expected that students can master the concept of communicative English sentences without being limited by language rules that are not always used and followed in non-formal communication. Learners will be able to have a new understanding of the composition of words into unlimited English sentences if arranged in a variety of words and can be understood if spoken and in accordance with the linguistic context. Therefore, based on the experience of the team, this service will make a positive contribution to the understanding of new English. This dedication not only describes learning in the classroom that might be monotonous for students but will also seek simulations of formal and informal atmosphere in communication.
\end{abstract}

Keywords_English communication skill, games method learning, community of Capung. 


\section{PENDAHULUAN}

Pembelajaran bahasa Inggris untuk anak-anak yang disebut Teaching English for Young Learners (TEYL) sedang berkembang di berbagai belahan dunia, terutama di negara-negara berkembang termasuk Indonesia. Kebijakan ini dimulai di Indonesia sejak diberlakukannya Kurikulum 1994, dan sampai saat ini terus semakin perlu ditingkatkan pelaksanaannya. Hal ini terkait dengan usaha pemerintah untuk menyiapkan para pebelajar yang handal dan berkualitas, yang nantinya mampu bersaing di tingkat nasional maupun Internasional.

Bagi masyarakat yang bermukim di Batam, pembelajaran bahasa Inggris yang diperkenalkan sejak dini sangat signifikan, karena Batam sebagai salah satu daerah tujuan pariwisata internasional menghendaki masyarakatnya untuk memiliki keterampilan berbahasa Inggris yang memadai khususnya pemanfaatan bahasa lisan, agar dapat berkomunikasi dengan wisatawan asing dari Negara tetangga dan juga berbagai negara lain. Di samping itu, masyarakat Batam sangat sadar bahwa dengan kemampuan berbahasa Inggris aktif akan membawa dampak positif dalam kehidupan (life skills). Disamping sektor pariwisata, berbagai peluang dan lowongan pekerjaan utamanya dalam bisnis pariwisata serta pekerjaan lain yang mensyaratkan kemampuan berbahasa Inggris.

Sebagai upaya untuk mencapai tujuan tersebut, bahasa Inggris menjadi mata pelajaran muatan lokal yang mulai diajarkan di sekolah dasar pada berbagai sekolah di kota Batam. Pengenalan bahasa Inggris sejak awal didasari oleh suatu konsep pedagogis bahwa semakin dini usia seseorang diperkenalkan dengan bahasa target, semakin cepat dan semakin bagus penguasaan dan pemerolehan anak terhadap bahasa yang dipelajari (Lesiak, 2015). Harapan masyarakat terhadap generasi yang cakap berbahasa asing terutamanya Bahasa Inngris dapat dilihat dari besarnya animo orang tua kepada anaknya untuk menggali potensi kemampuan Bahasa Inggris kepada anak-anaknya.

Secara hakiki, pembelajaran untuk anak-anak berbeda dengan pembelajaran untuk orang dewasa. Pembelajar anak-anak memiliki karakteristik yang berbeda dengan kelompok lain (Lesiak, 2015). Beberapa karakteristik mendasar dari anakanak adalah mereka senang bermain dan memiliki konsentrasi yang singkat. Dengan krakteristik tersebut, guru bahasa Inggris di sekolah dasar dan pemula semestinya menggunakan strategi atau teknik mengajar yang berbeda dengan para pebelajar bahasa lainnya.

Meskipun penerapan metode bermain selalunya diterapkan pada usia anakanak, akan tetapi pembelajaran Bahasa Inggris yang menerapkan metode bermain dapat juga dikondisikan pada usia remaja ata bahkan juga pada usia dewasa. Ini dikarenakan melalui metode bermain, peserta didik tidak akan dibebani dengan tuntutan tata aturan Bahasa, dan memerikan suasana santai tanpa merasa belajar formal. Hal yang sama diungkapkan oleh Hafidah (2013) yang melakukan penelitian tindakan kelas pada mahasiswa yang belajar bahasa Inggris, bahwa penggunaan game dapat meningkatkan penggunaan kosakata dan sekaligus dapat menunjang keberhasilan mahasiswa.

Bahasa adalah kemampuan dasar yang dimiliki manusia yang secara hakiki dapat dikuasai oleh semua orang yang normal. Dengan berpijak dari konsep berfikir 
manusia berkomunikasi dengan sesama, maka penguasaan bahasa Inggirs dapat dimilik oleh siapa saja yang berkemauan. Pembelajaran Bahasa Inggris yang laksanakan dengan permainan merupakan satu dari cara belajar Bahasa yang dapat dilaksanakan dalam suasana formal maupun informal.

Dalam sebuah obervasi penelitian yang dilakukan tim Pengabdi, didapati bahwa, materi pengajaran bahasa Inggris menggunakan buku teks yang sudah memenuhi karakter dan kognisi anak usia sekolah, namun dalam proses pengajarannya, penulis berkesimpulan bahwa para pengajar di sekolah-sekolah kurang dapat memaksimalkan model pembelajaran yang mampu melejitkan potensi peserta didik. Tim Pengabdi melihat potensi yang dimiliki oleh mereka yang bernaung dibawah komunitas capung yang menghuni daerah dengan potensi wisata di Batam, dapat ikut berperan aktif untuk kemajuan wisata di walayahnya. Dengan kemampuan dasar baahsa Inggris yang dimiliki mereka yang sudah melalui jenjang pendidikan formal, maka bahasa Inggris yang masih pasif tersebut dapat dioptimalkan untuk menjadi bahasa yang aktif dan komunikatif. Kendala yang dihadapi bagi sebahagian besar komunitas yang sadar wisata adalah kurangnya pemahaman bahwa bahasa adalah kemampuan dasar yang dimiliki oleh siapa saja yang berkemauan. jika penawaran pengabdian ini dapat terlaksana dan terprogram dengan baik, maka diharapkan komunitas ini akan memiliki motivasi untuk mengoptimalkan simpul simpul interaksi antar sesama komunitas dalam berbahasa Inggris di lingkungan tempat tinggal mereka.

\subsection{Permasalahan}

Masalah sesuai dengan analisis situasi di atas, ada beberapa masalah yang dapat diidentifikasi:

1. Pembelajaran Bahasa Inggris yang selama ini dialami adalah masih berfokus pada pemanfaatan utama buku teks, sehingga pembelajaran menjadi kegiatan rutinitas yang kurang menyenangkan.

2. Pembelajaran di sekolah formal yang selama ini dijalani adalah cenderung bersifat konvensional, yaitu guru menjadi figur aktif, mengajarkan pelafalan setiap kosakata, melalui latihan pengulangan, dan kemudian menjelaskan makna setiap kosakata bahasa Inggris dengan menerjemahkan.

3. Belum tersedianya alat peraga yang dapat menstimulus pembelajara bahasa Inggris yang menyenangkan dan komunikatif.

4. Media yang dipilih belum selaras dan menunjang tujuan pembelajaran yang telah ditetapkan, yang seyogyanya harus jelas, operasional, spesifik, dan benar-benar tergambar dalam bentuk perilaku.

5. Kurangnya interaksi dengan praktisi pengajar bahasa Inggris setelah menamatkan bangku sekolah dan lingkungan yang belum mendukung pembelajara Bahasa Inggris yang komunikatif.

Mengacu pada masalah-masalah yang teridentifikasi di atas, maka upaya yang dapat dalam pengabdian ini adalah:

a) Bagaimana meningkatkan pengetahuan dan keterampilan peserta didik sebagai pembelajar bahasa Inggris dalam meningkatkan kemampuan komunikasi dalam bahasa Inggris? 
b) Bagaimana meningkatkan keterampilan berbahsa Inggris yang yang relevan dan efektif?

\subsection{Solusi yang ditawarkan melalui pengabdian kepada masyarakat}

Penggunaan alat peraga pada pembelajaran bahasa Inggris merupakan salah satu upaya untuk menumbuh-kembangkan minat belajar bahasa Inggris. Alat peraga adalah alat-alat yang digunakan pengajar dalam pembelajaran dan mencegah terjadinya verbalisasme pada diri peserta didik. Fungsi utama dari alat peraga adalah untuk menurunkan keabstrakan dari konsep serta memunculkan visualisasi tentang konsep kata bahasa Inggris pada diri peserta didik, agar peserta didik mampu menangkap arti sebenarnya konsep tersebut. Dengan melihat, meraba, dan mengkreasikan alat peraga seperti flash card susun kata maka peserta didik mempunyai pengalaman pengalaman konkret dalam penggunaan variasi kalimat di kehidupan sehari-hari. Secara terperinci, nilai atau manfaat alat peraga menurut Encyclopedia of Educational Research adalah sebagai berikut:

a. Meletakkan dasar-dasar yang konkret untuk berpikir.

b. Memperbesar perhatian peserta didik dalam pembelajaran bahasa Inggris.

c. Membuat pelajaran lebih menetap atau tidak mudah dilupakan.

d. Memerikan pengalaman yang nyata yang dapat menumbuhkan kegiatan berusaha sendiri di kalangan para siswa.

e. Menumbuhkan pemikiran yang teratur dan berkelanjutan.

f. Membantu tumbuhnya pengertian dan membantu perkembangan kemampuan berbahasa Inggris.

g. Menyebabkan agar hasil belajar lebih permanen dan mantap.

h. Memerikan alasan yang wajar untuk belajar karena membangkitkan minat perhatian (aktivitas pada peserta didik).

i. Memerikan pemahaman yang lebih tepat dan jelas.

Umumnya, peserta didik belajar melalui sesuatu yang konkrit. Untuk memahami konsep abstrak peserta didik memerlukan benda konkrit sebagai perantara atau visualisasinya. Konsep abstrak itu dicapai melalui tingkatan belajar yang berbeda-beda. Maksud dan tujuan alat peragaan adalah memerikan variasi dalam cara pendidik mengajar dan memerikan lebih terwujud, lebih terarah untuk mencapai tujuan pembelajaran (Azhar, 2011).

Adapun langkah-langkah solusi yang diberikan untuk anggota komunitas Capung Kampung Tua Nongsa sesuai dengan permasalahannya adalah:

1. Mengetahui kendala yang spesifik yang dihadapi dalam berbahasa Inggris sehingga dapat mengetahui jenis/tingkat pelatihan yang dilaksanakan melalui wawancara dan observasi.

2. Memerikan pretest berupa wawancara sederhana dengan bahasa Inggris untuk mengetahui kemampuan bahasa Inggris anggota Capung Kampung Tua Nongsa.

3. Memerikan pelatihan bahasa Inggris khususnya pelatihan merangkai kalimat dari system permainan kartu sebagai alat peraga sebanyak dua kali

4. Memerikan pelatihan sebanyak satu kali tentang teori merangkai kalimat dalam bahasa Inggris. 
Tabel 1 Kegiatan Pelatihan

\begin{tabular}{|c|c|c|}
\hline No & Pertemuan & Kegiatan \\
\hline 1 & 1 & $\begin{array}{l}\text { - Memerikan motivasi tentang pentingnya berbahasa } \\
\text { Inggris pada saat ini. } \\
\text { - Pembelajaran grammar bahasa Inggris secara dasar } \\
\text { sebagaimana pembentukan ekpresi kalimat dalam } \\
\text { bahasa Inggris. } \\
\text { - Pengarahan tentang metode dan manfaat permainan } \\
\text { dalam susun kata bahasa Inggris. } \\
\text { - Permainan susun kata dalam bahasa Inggris. } \\
\text { - Membahas kalimat yang diproduksi oleh peserta didik }\end{array}$ \\
\hline 2 & 2 & $\begin{array}{l}\text { - Melanjutkan pelatihan pembelajaran konsep kalimat } \\
\text { dan ekpresi bahasa Inggris. } \\
\text { - Melatih pelajar merangkai kalimat-kalimat bahasa } \\
\text { Inggris dengan permainan susun kata. } \\
\text { - Melatih peserta didik mengucapkan kalimat dengan } \\
\text { benar. } \\
\text { - Melatih peserta didik mebetulkan kalimat yang salah } \\
\text { dari peserta didik lain. } \\
\text { - Membahas hasil permainan susun kata dalam konsep } \\
\text { Bahasa yang informal dan formal. } \\
\text { - Menggabungkan kalimat kalimat yang telah disusun } \\
\text { dalam percakapan yang komunikatif. }\end{array}$ \\
\hline
\end{tabular}

5. Memerikan praktik langsung berbahasa Inggris anggota komunitas Capung melalui simulasi (posttest).

\section{METODE PELAKSANAAN}

\subsection{Waktu Dan Tempat Pelaksanaan}

Kegiatan pengabdian kepada masyarakat ini dilakukan secara bertahap mulai tanggal 16 Desember 2018 sampai dengan 23 Desember 2018 yang terbagi menjadi 2 pertemuan di Nongsa, Batu Besar seperti yang dijelaskan pada tabel berikut ini:

Tabel 2 Waktu dan Tempat Pelaksanaan

\begin{tabular}{|c|c|c|c|c|c|}
\hline No & Tanggal & Waktu & $\begin{array}{c}\text { Tempat } \\
\text { Pelaksanaan }\end{array}$ & Kegiatan & $\begin{array}{c}\text { Penanggung } \\
\text { Jawab }\end{array}$ \\
\hline 1 & $\begin{array}{l}16 \\
\text { Desember } \\
2018\end{array}$ & $\begin{array}{c}15.00- \\
17.00\end{array}$ & $\begin{array}{l}\text { Kampung Tua } \\
\text { Nongsa Batu } \\
\text { Besar }\end{array}$ & $\begin{array}{l}\text { Pelatihan Teori } \\
\text { Bahasa Inggris } \\
\text { dasar dan } \\
\text { permainan } \\
\text { susun kata. }\end{array}$ & $\begin{array}{l}\text { Ketua Tim } \\
\text { Pengabdi }\end{array}$ \\
\hline 2 & $\begin{array}{l}23 \\
\text { Desember } \\
2018\end{array}$ & $\begin{array}{l}15.00- \\
17.00\end{array}$ & $\begin{array}{l}\text { Kampung Tua } \\
\text { Nongsa Batu } \\
\text { Besar }\end{array}$ & $\begin{array}{l}\text { Pelatihan Susun } \\
\text { Kata dan } \\
\text { pengucapan } \\
\text { Bhasa Inggris } \\
\text { yang baik dan } \\
\text { Benar dalam }\end{array}$ & $\begin{array}{l}\text { Ketua Tim } \\
\text { Pengabdi }\end{array}$ \\
\hline
\end{tabular}


Untuk lebih jelasnya lokasi pengabdian yang dilaksanakan di Kampung Tua Nongsa, Batu Besar dapat dilihat pada peta dan gambar di bawah ini:

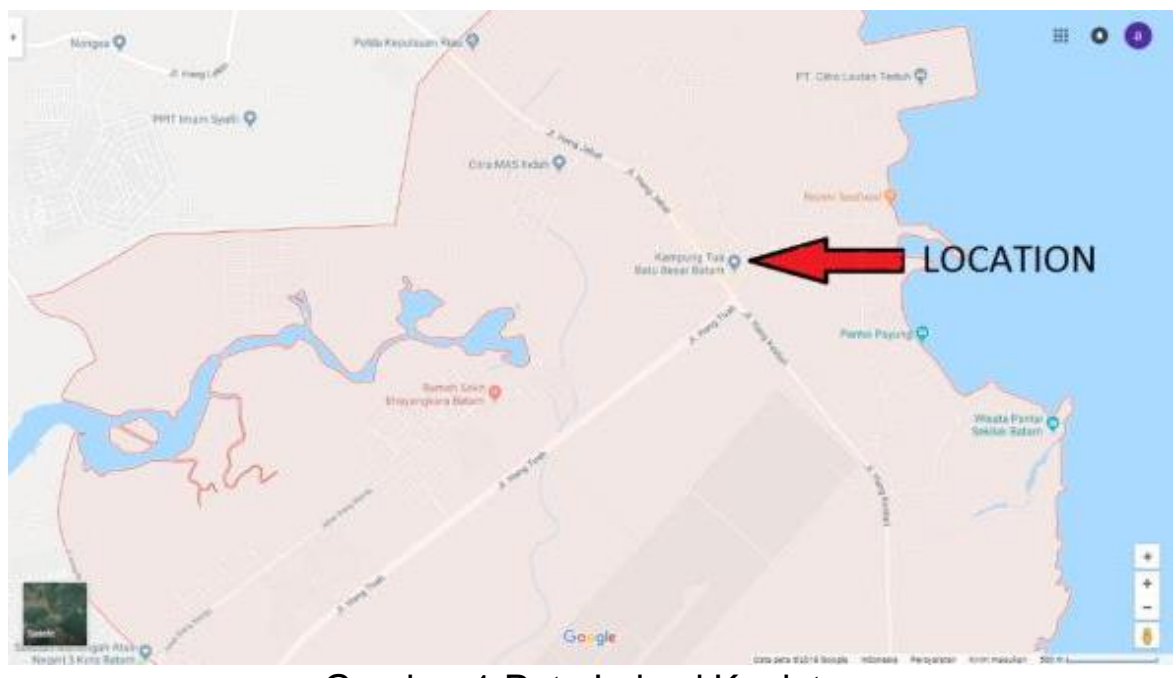

Gambar 1 Peta Lokasi Kegiatan

\subsection{Metode Pelaksanaan}

Metode yang ditawarkan dalam menyelesaikan permasalahan oleh tim pengabdi adalah:

1. Ketua tim pengabdi akan melaksanakan wawancara untuk mengetahui kemampuan berbahasa Inggris anggota komunitas Capung sebagai pelajar dewasa yang bekerja dan mengkondisikan dengan tim pengabdi lain di lokasi yang sama.

2. Pretest di berikan kepada peserta didik anggota komunitas Capung berbentuk tanya-jawab sederhana dalam bahasa Inggris untuk mengetahui kemampuan bahasa Inggris peserta dan latihan kemahiran bahasa inggris yang awal dimiliki.

3. Ketua tim pengabdi dibantu seorang mahasiswa melaksanakan pelatihan teori dasar bahasa Inggris dan pengucapan bahasa Inggris secara dasar sebagai latar belakang sebelum permainan susun kata sebagai metode utama.

4. Ketua tim pengabdi dibantu mahasiswa anggota 1 melaksanakan permainn susun kata dari alat peraga yang biasa disebut flashcard, dengan sistem permainan susun kata dan acak kata.

5. Hasil permainan susun kata dan acak kata akan didiskusikan dan dihubungkan dengan teori kalimat bahasa Inggris yang baik dan benar.

6. Pengucapan kalimat yang baik dan benar dilakukan sebagai latihan mendukung kemampuan susun kata dari peserta didik.

7. Masing masing peserta didik yang telah menyusun kata akan menjelaskan maksud kalimat yang disusun dan menshare hasil susun kata dana artinya kepada peserta didik lain. Dengan demikian peserta didik lain akan memerikan feedback dan mendapat feedback. 
8. Ketua tim pengabdi akan memerikan input dan membahas setiap kalimat yanng telah disusun. Permainan susun kata diharapkan akam memerikan suasana belajar bahasa Inggris yang menyenangkan dan menarik.

\subsection{Evaluasi Pelaksanaan Kegiatan}

Evaluasi pelaksanaan kegiatan pelatihan bahasa Inggris memiliki tujuan untuk melihat pencapaian kegiatan dalam pengabdian dan perbaikan yang dianggap perlu bagi kegiatan pengabdian di masa yang akan datang. Evaluasi pelaksanaan kegiatan pengabdian adalah:

1. Tahap Sebelum Kegiatan

Tim pengabdi akan melihat bagaimana hambatan atau kendala yang dihadapi oleh tim pengabdi baik saat observasi lokasi pengabdian, dukungan pimpinan, motivasi anggota komunitas Capung dalam mengikuti kegiatan pelatihan, dan evaluasi hasil pre-test dan post-test sebagai perbandingan sebelum dan sesudah pelatihan.

2. Tahap Saat Pelaksanaan Kegiatan

Pada tahapan ini tim pengabdi akan melihat antara lain: bagaimana motivasi peserta didik di dalam pelaksanaan pembelajaran Bahasa Inggris yang menggunakan metode permainan susun kata.

3. Tahap Setelah Kegiatan

Pada tahap ini, tim pengabdi akan mengevaluasi secara langsung akan dampak perubahan yang terjadi sebelum dan sesudah pelatihan dalam kemampuan merangkai kalimat berbahasa Inggris. Ukuran motivasi dapat diukur dari proses komunikasi bahasa Inggris yang yang dikuasai oleh anggota komunitas Capung setelah mendapatkan pelatihan dari tim pengabdi.

\subsection{Keberlanjutan Kegiatan}

Kegiatan pengabdian akan memerikan inspirasi kepada peserta didik pada komunitas Capung dalam belajar bahasa Inggris dalam berbagai metode yang menyenangkan dan menarik. Sistem permainan adalah salah satu alat untuk menstimulus kreatifitas belajar bahasa Inggris yang menguatkan sisi afektif, kognitif dan psikomotorik. Kemahiran berbahasa Inggris akan memerikkan peluang yang baik bagi anggota komunitas Capung dan masyarakat dalam sehingga dapat berinteraksi dengan wisatawan asing. Harapan jangka panjang tentunya dapat menumbuhkembangkan Wisata Kampung Tua Nongsa.

Pelaksanaan pengabdian anggota komunitas Capung dan masyarakat, yang tidak mampu menggunakan bahasa Inggris lisan dan tulisan dengan baik dan benar, akan dilaksanakan 2 kali pertemuan tentunya tidak cukup, oleh sebab itu perlu ada keberlanjutan kegiatan. Setelah diadakan kegiatan pengabdian, tim pengabdi akan melakukan pantaun (follow-up) anggota komunitas Capung dan masyarakat untuk mengetahui ilmu Bahasa Inggris yang telah diperoleh dapat dipergunakan. Harapan jangka pendek dan menengah adalah memerikan warna baru dalam pendekatan belajar Bahasa Inggris dengan permainan.

Kegiatan keparawisataan Kampung Tua Nongsa tidak hanya sekali dilakukan tetapi akan terus berlanjut sampai ke generasi selanjutnya. Tim pengabdi akan 
melakukan pelatihan lanjutan yang disesuaikan dengan kondisi dan kebutuhan anggota komunitas Capung dan masyarakat jika diperlukan.

\subsection{Hasil Pengabdian}

\section{HASIL DAN PEMBAHASAN}

Pengabdian yang telah dilaksanakan mempunyai beberapa tujuan, indikator dan tolak ukur. Pada tabel 3, pengabdian dilaksanakan dengan menyesuaikan konsisi lapangan dan jadwal peserta didik. Masing masing tujuan, indikator ketercapaian dan tolak ukur dicatat di ringkas dalam laporan pengabdian. Para peserta pengabdian membagi tugas didalam penyampaian materi dengan memecah tim menjadi dua kelas. Pada kelas yang usia anak anak, satu pengabdi Dosen dan Mahasiswa UPB terlibat dalam mengarahkan peserta untuk berpartisipasi aktif dalam permainan dan pembelajaran Bahasa Inggris.

Tabel 3 Hasil Pelaksanaan Kegiatan Pengabdian

\begin{tabular}{|l|l|l|}
\hline \multicolumn{1}{|c|}{ Tujuan } & \multicolumn{1}{c|}{ Indikator Ketercapaian } & \multicolumn{1}{c|}{ Tolok Ukur } \\
\hline $\begin{array}{l}\text { Peserta pembinaan } \\
\text { memiliki semangat } \\
\text { belajar Bahasa Inggris } \\
\text { yang tinggi. }\end{array}$ & $\begin{array}{l}\text { Peserta memiliki motivasi } \\
\text { dalam menguasai } \\
\text { kosakata bahasa Inggris. }\end{array}$ & $\begin{array}{l}\text { Peserta melakukan } \\
\text { praktek secara verbal } \\
\text { dan tertulis atas materi } \\
\text { yang diberikan. }\end{array}$ \\
\hline $\begin{array}{l}\text { Peserta pembinaan dapat } \\
\text { memahami tata bahasa } \\
\text { secara alamiah secara } \\
\text { verbal dari permainan } \\
\text { kosakata bahasa inggris. }\end{array}$ & $\begin{array}{l}\text { Peserta dapat } \\
\text { memaksimalkan } \\
\text { kemampuan menyusun } \\
\text { kata dalam kalimat } \\
\text { sederhana dan dapat } \\
\text { dimengerti lawan bicara. }\end{array}$ & $\begin{array}{l}\text { Hasil pemahaman } \\
\text { peserta pengabdi dapat } \\
\text { diterapkan dalam } \\
\text { komunikasi verbal sesuai } \\
\text { kebutuhan. }\end{array}$ \\
\hline $\begin{array}{l}\text { Peserta pembinaan dapat } \\
\text { mengembangkan contoh- } \\
\text { contoh permainan } \\
\text { kosakata dalam } \\
\text { menyususn kalimat di } \\
\text { berbagai situasi verbal }\end{array}$ & $\begin{array}{l}\text { Peserta menjadi terampil } \\
\text { menyusun kalimat melalui } \\
\text { kata yang dimiliki. }\end{array}$ & $\begin{array}{l}\text { Peserta pengabdian } \\
\text { dapat meminimalisasi } \\
\text { keraguan didalam } \\
\text { suasana komunikasi } \\
\text { verbal bahasa Inggris. }\end{array}$ \\
\hline \multicolumn{2}{|l}{} & \multicolumn{2}{|l}{} \\
\hline
\end{tabular}

Adapun materi yang disampaikan berupa teori dan praktek dengan capaian yang telah ditetapkan oleh tim pengabdi. Untuk lebih jelasnya dapat dilihat pada tabel dibawah ini:

Tabel 4 Materi Pengabdian dan capaian yang diharapkan

\begin{tabular}{|c|c|c|}
\hline & Kegiatan dan materi pembelajaran & $\begin{array}{l}\text { Capaian yang } \\
\text { diharapkan }\end{array}$ \\
\hline $\begin{array}{l}\text { Materi } 1 \\
\text { (Teori) }\end{array}$ & $\begin{array}{l}\text { - Tim pengabdi menerangkan secara } \\
\text { ringkas tentang struktur kalimat Bahasa } \\
\text { Inggris dalam penyampaian yang } \\
\text { ringkas. } \\
\text { - Penjelasan yang ringkas dimaksudkan } \\
\text { untuk mengulang apa yang sudah dimiliki } \\
\text { oleh peserta didik dan untuk }\end{array}$ & $\begin{array}{l}\text { Tim Pengabdi } \\
\text { diharapkan } \\
\text { mendapat gambaran } \\
\text { tentang kemampuan } \\
\text { peserta didik dalam } \\
\text { pengetahuan } \\
\text { tentang Bahasa }\end{array}$ \\
\hline
\end{tabular}




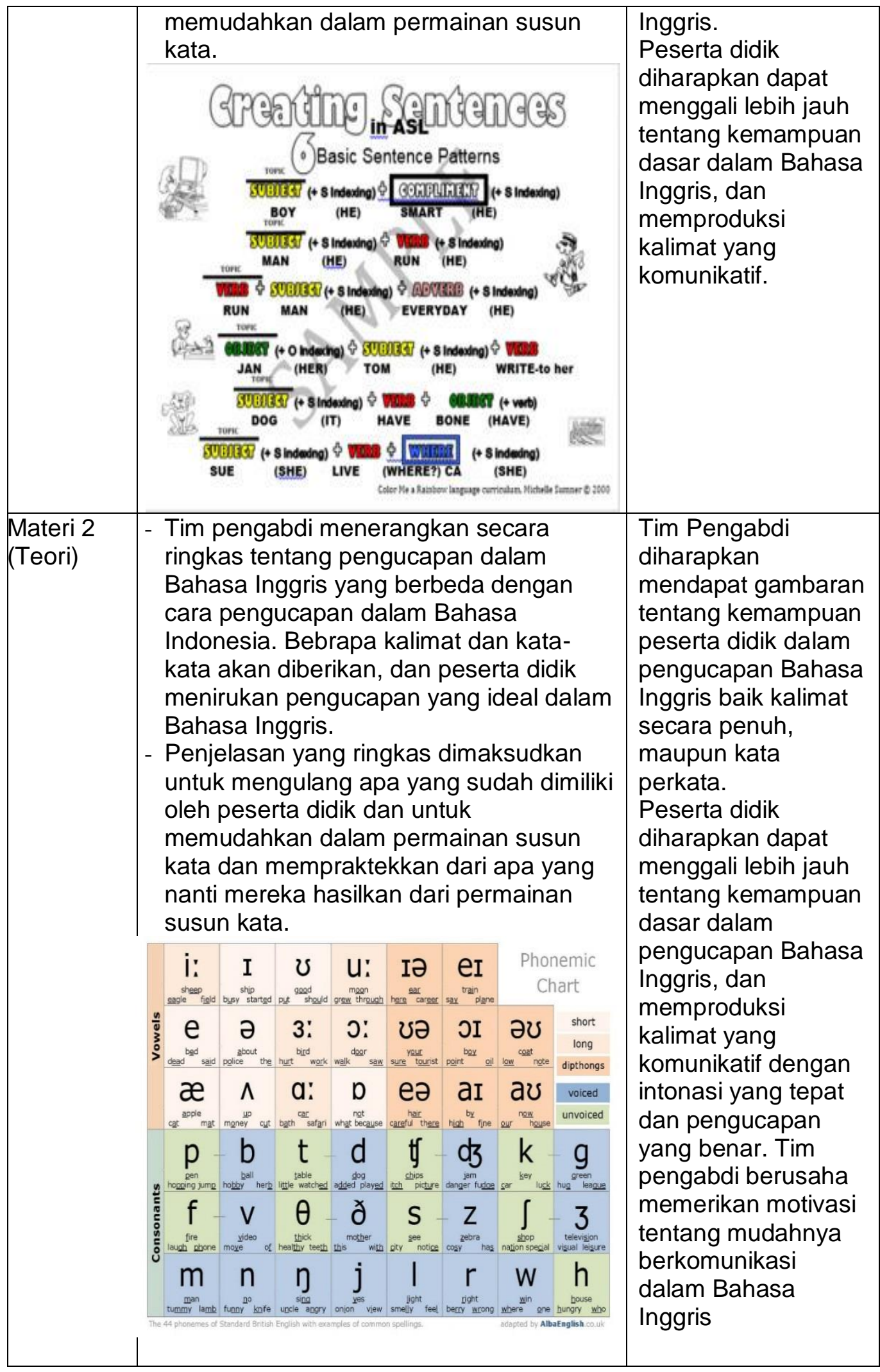




\begin{tabular}{|c|c|c|}
\hline & Kegiatan dan materi pembelajaran & $\begin{array}{l}\text { Capaian yang } \\
\text { diharapkan }\end{array}$ \\
\hline $\begin{array}{l}\text { Materi 3 } \\
\text { (Praktek } \\
\text { berupa } \\
\text { permainan) }\end{array}$ & $\begin{array}{l}\text { Tim Pengabdi mengawali dengan doa, } \\
\text { dan melanjutkan dengan tehnis permainan } \\
\text { susun kata: } \\
\text { 1. Peserta didik akan dibagi menjadi 3-5 } \\
\text { orang. } \\
\text { 2. Kartu yang terdiri dari kata dan joker, } \\
\text { peserta didik mendapatkan } \\
\text { kesempatan untuk mengambil satu } \\
\text { kartu dan mengucapkannya dengan } \\
\text { keras. } \\
\text { 3. Peserta didik akan diminta untuk } \\
\text { menyusun kata sesuai dengan tata } \\
\text { Bahasa Inggris. Kartu joker adalah } \\
\text { opsi kata yang cocok untuk semua } \\
\text { jenis kata agar kalimat dapat dibentuk } \\
\text { dari rangkaian kata yang ada. } \\
\text { 4. Peserta didik diharapkan berfikir } \\
\text { bagaimana memproduksi kata dari } \\
\text { rangkaian kata yang didapat dari } \\
\text { undian kata tersedia. } \\
\text { 5. Peserta didik diminta untuk menuliskan } \\
\text { di papan tulis dari kalimat apa yang } \\
\text { telah mereka susun. } \\
\text { 6. Peserta didik lain akan menyimak dan } \\
\text { memerikan masukan. } \\
\text { 7. Permainan ini akan dilakukan pada } \\
\text { hari pertama dan kedua. } \\
\text { 8. Tim Pengabdi akan memerikan } \\
\text { penerangan yang dianggap perlu dari } \\
\text { kata yang telah disusun menjadi } \\
\text { kalimat dan pengucapan yang sesuai } \\
\text { dengan kaidah Bahasa Inggris. }\end{array}$ & $\begin{array}{l}\text { Tim Pengabdi akan } \\
\text { mendapatkan } \\
\text { masukan dari } \\
\text { peserta didik tentang } \\
\text { kesulitan } \\
\text { memproduksi } \\
\text { kalimat dari } \\
\text { rangkaian kata yang } \\
\text { ada. } \\
\text { Peserta didik akan } \\
\text { mendapatkan } \\
\text { pengalaman } \\
\text { menyusun kata dan } \\
\text { pengalaman } \\
\text { mengucapkan } \\
\text { Bahasa dari } \\
\text { probabilitas kata } \\
\text { yang muncul. } \\
\text { Peserta didik juga } \\
\text { akan mendapatkan } \\
\text { pengalaman dari } \\
\text { teman bermain } \\
\text { dalam satu tim dan } \\
\text { tim yang terpisah } \\
\text { dalam kelompok } \\
\text { tentang kalimat dan } \\
\text { pengucapan Bahasa } \\
\text { Inggris. }\end{array}$ \\
\hline
\end{tabular}


Adapun beberapa foto kegiatan selama pengabdian, dapat dilihat pada gambargambar di bawah ini:

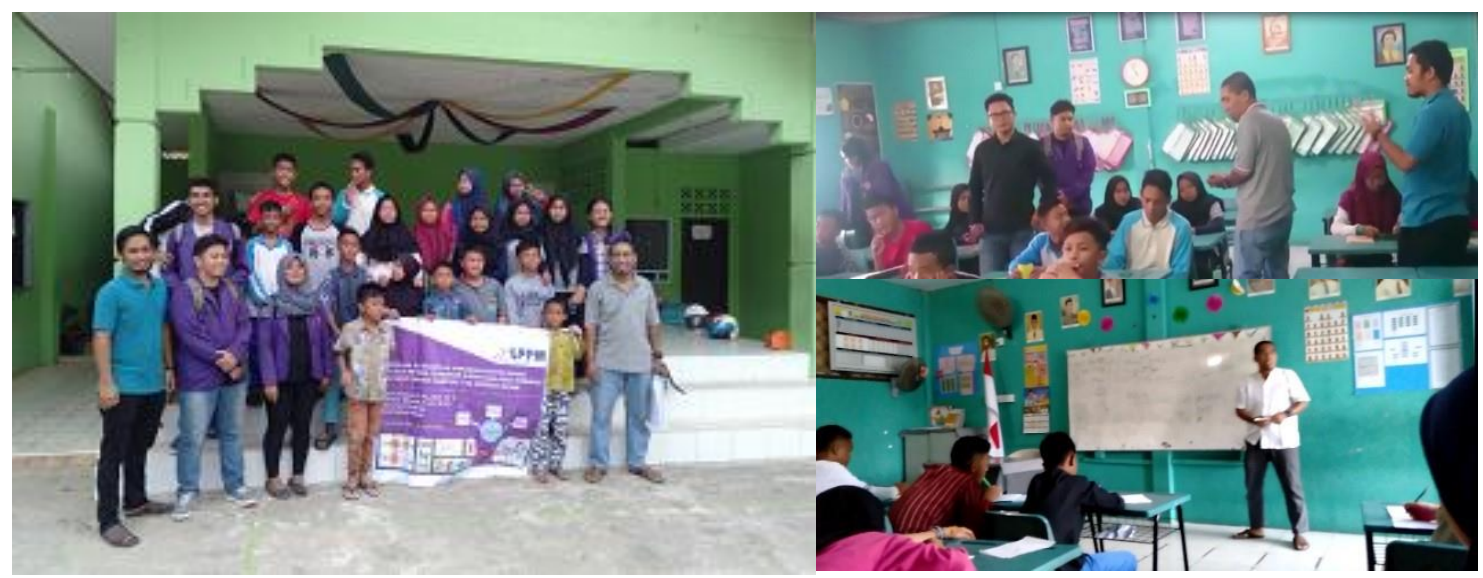

Gambar 2 Kegiatan Pengabdian hari pertama

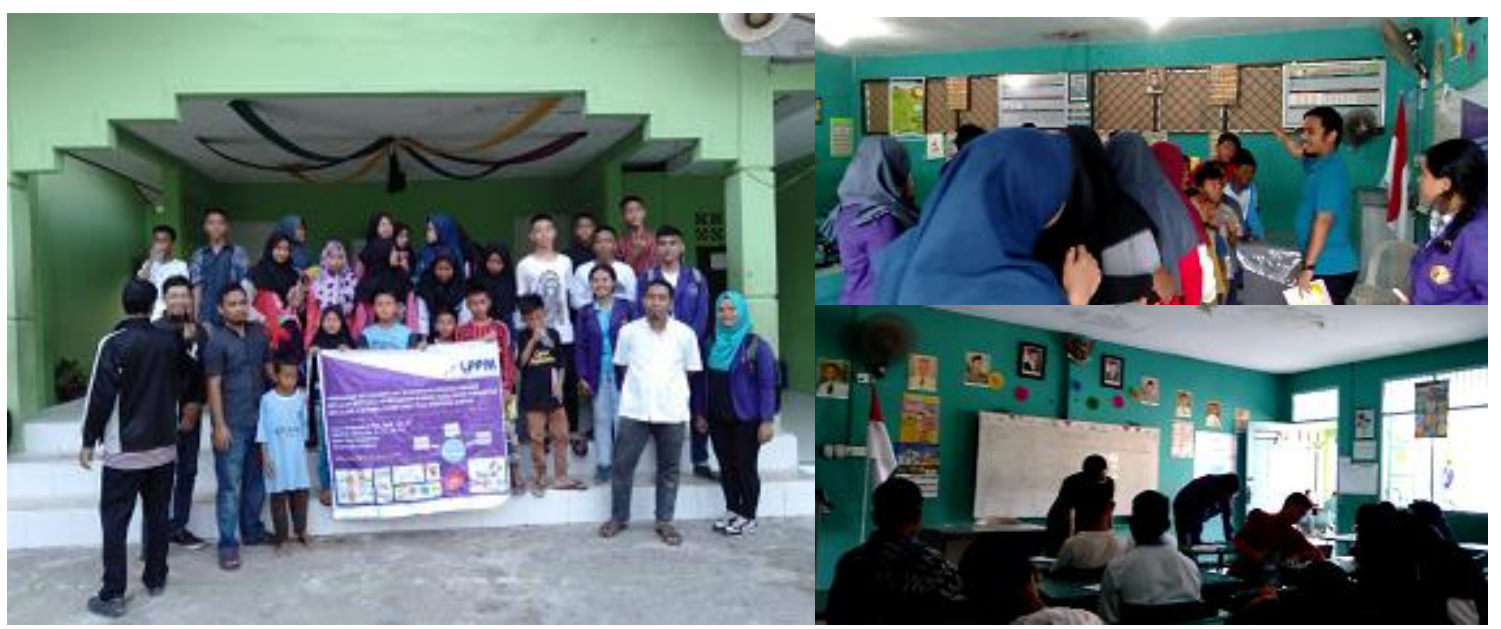

Gambar 3 Kegiatan Pengabdian hari ke dua

\subsection{Pembahasan}

Keberlanjutan kegiatan pengabdian dapat dilakukan secara berperiode dan jangka waktu tertentu. Kegiatan pembinaan ini bertujuan untuk membantu anakanak usia remaja di komunitas belajar Capung Nongsa Batam didalam berkomunikasi dengan memanfaatkan potensi yang dimiliki. Kemampuan komunikasi bahasa Inggris verbal akan berguna begitu mereka terjun di dunia kerja dan bisnis. Pendekatan belajar yang dilakukan adalah upaya belajar dengan meningkatkan motivasi melalui permainan dalam Bahasa Inggris. Permainan kosakata dipilih karena secara prinsip, kosakata merupakan hal dasar untuk dikuasai 
dalam Bahasa Inggris. Selanjutnya peserta akan dapat membiasakan diri dalam bahasa verbal menggunakan tata bahasa yang tidak formal tetapi kosakata yang sesuai dengan kondisi dan konteks. Dengan adanya kegiatan pelatihan ini, dapat disampaikan kepada peserta didik tentang motivasi belajar bahasa Inggris yang perlu keberlanjutan dan hal dasar yang dapat mereka kuasai dan belajar mandiri sehingga hasilnya tepat sasaran sesuai dengan tujuan kegiatan pengabdian kepada masyarakat. Dengan adanya kegiatan pengabdian ini juga dapat memberikan input dan solusi tepat bagi peserta tentang pentingnya penguasaan kosakata melalui strategi belajar kosakata dan aplikasinya didalam keseharian.

\section{KESIMPULAN}

Dengan pelatihan ini diharapkan peserta didik akan lebih maksimal dan dapat meningkatkan kemampuan bahasa inggris dengan lebih baik lagi. Dasar pengabdian ini telah diarahkan dan ditujukan pada pelatihan yang membangun siswa yang berkarakter dan berdaya saing khususnya mempunyai kemampuan komunikasi bahasa Inggris dengan benar dan dalam konteks yang tepat.

\section{SARAN}

Dari pengabdian ini, disarankan agar siswa lebih semangat menggunakan bahasa inggris didalam dan diluar kelas, karena dengan demikian kemampuan akan lebih terasah dan rasa kepercayaan diri akan meningkat seiring kemampuan bahasa yang semakin lancar. Semakin sering pneggunaan kata-kata yang rutin dan umum didalam kerja praktek sehari hari akan membantu mensimulasi dunia kerja yang sesungguhnya.

\section{DAFTAR PUSTAKA}

Azhar, A. (2011). Media Pembelajaran. Jakarta: Rajawali Pers.

Hafidah, R. (2013). Penggunaan Games Untuk Meningkatkan Penguasaan Vocabulary Sebagai Penunjang Mata Kuliah Bahasa Inggris Mahasiswa Kelas Paser Prodi PG-PAUD FKIP UNS.

Kaltsum, H. U. (2017). Pemanfaatan Alat Peraga Edukatif Sebagai Media Pembelajaran Bahasa Inggris Sekolah Dasar. The 6th University Research Colloquium: Universitas Muhammadiyah Magelang.

Lesiak, K. (2015). Teaching English to adolescents. World Scientific News 1 246-260 EISSN 2392-2192. www.worldscientificnews.com. 